\title{
Article
}

\section{Futsal as a potential talent development modality for soccer - a quantitative assessment of high-level soccer coach and player perceptions}

Yiannaki, Christopher, Carling, Christopher and Collins, David John Available at http://clok.uclan.ac.uk/22876/

Yiannaki, Christopher, Carling, Christopher ORCID: 0000-0002-7456-3493 and Collins, David John ORCID: 0000-0002-7601-0454 (2018) Futsal as a potential talent development modality for soccer - a quantitative assessment of highlevel soccer coach and player perceptions. Science and Medicine in Football, 2 (4). pp. 299-308. ISSN 2473-3938

It is advisable to refer to the publisher's version if you intend to cite from the work. http://dx.doi.org/10.1080/24733938.2018.1483079

For more information about UCLan's research in this area go to http://www.uclan.ac.uk/researchgroups/ and search for <name of research Group>.

For information about Research generally at UCLan please go to http://www.uclan.ac.uk/research/

All outputs in CLoK are protected by Intellectual Property Rights law, including Copyright law. Copyright, IPR and Moral Rights for the works on this site are retained by the individual authors and/or other copyright owners. Terms and conditions for use of this material are defined in the policies page. 
Title: Futsal as a potential talent development modality for soccer - a quantitative assessment of high-level soccer coach and player perceptions

Authors: Christopher Yiannaki ${ }^{1}$ Christopher Carling ${ }^{2}$, Dave Collins ${ }^{2}$

Institutions:

${ }^{1}$ Centre for Research in Sports Performance, Myerscough College, Bilsborrow, Preston, UK. ${ }^{2}$ Institute of Coaching and Performance, University of Central Lancashire, Preston, United Kingdom.

Correspondence: Christopher Carling, Institute of Coaching and Performance, Greenbank Building, University of Central Lancashire, Preston, United Kingdom.

Email: ccarling@uclan.ac.uk, telephone: +44 17927937987.

Key words: football, small-sided games, talent, skill acquisition, futsal

Word Count: 3860

Declaration of Conflicting Interests

The author(s) declared no potential conflicts of interest with respect to the research, authorship, and/or publication of this article.

Funding

The author(s) received no financial support for the research, authorship, and/or publication of this article. 


\section{Abstract}

A contemporary issue in soccer talent development is the potential use of futsal as a training tool. This paper utilised survey methods to quantitatively assess the perspectives of high-level coaches working in youth player education, and players of futsal and 11-a-side soccer $(n=77)$. Respondents completed surveys before and following a showcase game between an Under-21 international futsal team competing against a Premier League Under-21 soccer team. Responses were positive about futsal generally as a training aid and specifically, skills transfer from futsal into soccer performance. The majority of respondents $(89.6 \%)$ indicated 'postgame' that they considered futsal could be useful for soccer talent development. Similarly, $90.9 \%$ stated they would consider its integration in their training/games program. Analysis of opinions on futsal regarding its constraints and the impact its specific rules may have on skill acquisition generally reported positive perceptions: $89.6 \%$ of participants suggested that pitch size improved skills ( strongly agree $=33.8 \%$, agree $=55.8 \%$ ), $88.3 \%$ believed the pass back rule enhanced ball reception skills (strongly agree $=27.3 \%$, agree $=61 \%$ ), and $89.2 \%$ perceived that futsal can help develop 'multifunctional' players (strongly agree $=27.3 \%$, agree $=62.3 \%$ ). This knowledge of the constraints and potential for skill acquisition linked to futsal participation is a first step in aiding soccer coaches to understand potential learning returns from its inclusion in talent development policies and programs. 
Title: Futsal as a potential talent development modality for soccer - a quantitative assessment of high-level soccer coach and player perceptions

\section{Introduction}

Soccer has grown into a multi-million Euro marketplace where the pressure to achieve success is high (Elferink-Gemser, Huijgen, Lemmink, Visscher, \& Coelho-e-Silva, 2012). The economic benefits are obvious to elite clubs that are able to identify, recruit and subsequently develop talented players to their full potential (Unnithan, White, Georgiou, Iga, \& Drust, 2012). It is, therefore, essential to create effective elite youth talent development programs based substantially on scientific evidence (Güllich \& Emrich, 2014; Horrocks, McKenna, Whitehead, Taylor, \& Morley, 2016). Models such as those identified by Gagné, (2013) have been used to support this talent development process, with countries such as England (The Premier League, 2011) and Germany (Grossmann \& Lames, 2015) developing their own unique systems.

Within the talent development process for soccer, the microstructure content of curriculums is important (Hornig, Aust, \& Güllich, 2016). While there is a broad acceptance that the quantity of training accumulated is important (Ericsson, Krampe, \& Tesch-Römer, 1993), the quality and type of training sessions are particularly decisive in aiding talent development (Gagné, 2013; Mills, Butt, Maynard, \& Harwood, 2012). One commonly used method of training is Small Sided Games (SSG) which forms a significant element of contemporary coaching curriculums/microstructures (Aguiar, Botelho, Lago, Maças, \& Sampaio, 2012). In general, SSG condense the number of actions and decisions players make, whilst creating the random practice and physical demands necessary for habituating players to match-like conditions (Clemente, Couceiro, Martins, \& Mendes, 2012). 
An emerging question in soccer talent development programs is the potential use of the SSG 'Futsal' (Travassos, Araujo, \& Davids, 2017; Yiannaki, Carling, \& Collins, 2018). Futsal is the indoor 5-a-side equivalent to 11 a-side soccer, with FIFA and UEFA recognising futsal as an official sport, with standardised rules and game formats (Sturgess, 2017). Yet while in recent years The FA Premier League has invested £320m into their Elite Player Performance Plan ('EPPP') (The Premier League, 2011) in England, a recent paper (Yiannaki et al., 2018) has criticised this plan and talent development programs in general for showing little consideration to futsal despite its potential for aiding player development. Indeed, anecdotal evidence from player interviews reports that several international level soccer players regularly participated in futsal play at a younger age (UEFA, 2017). Scientific evidence from the analysis of 'practice histories' of elite academy players also shows futsal participation was widespread in players from South American countries such as Brazil (Ford et al., 2012a). A central debate therefore, is the potential for skills to transfer from futsal to soccer, with research suggesting that high similarity is a decisive factor in this regard (Causer \& Ford, 2014). Given the genesis of futsal, it is logical that many of the techniques and skills will be similar to soccer, (Milligan, Borrie, Horn, \& Williams, 2002; Travassos et al., 2017), and therefore it could be hypothesised that transfer is probable. To our knowledge however, no study has attempted to determine whether players and particularly coaching practitioners perceive there is a place for futsal in player development for elite soccer. Coach and player perceptions of factors affecting talent development in soccer are generally underrepresented in the talent development literature and an understanding of perceptions may influence developmental practices (Gledhill, Harwood, \& Forsdyke, 2017). The objective of this study therefore is to quantify the opinions of a sample of high-level soccer coaches and players on the potential use of futsal as a tool for aiding soccer talent development. 


\section{Methodology}

\section{Context}

In English elite soccer, the highest-ranking youth talent development programs are found in elite club academies. These academies are created and funded by professional clubs with the vision of nurturing professional players for their first team. These academies are part of the Elite Player Performance Plan (EPPP) and fall into one of four categories based on their ranking/quality, with stipulations set by the governing bodies (The Premier League, 2011). Youth players are educated from ages 9-16 before players progress into professional 'scholarships' $18+$ and beyond. The coaches working within these academies are evidently the most crucial influences in talent development during the formative years for children, whilst also being the most highly qualified youth coaches in England attaining higher qualifications (UEFA 'A'/'B') stipulated by governing bodies and clubs. Furthermore, the players selected for these programs are the most elite youth players in the country and are affiliated to professional clubs. This study, therefore captures a unique population of participants involved within professional football and the highest-ranking academies in the country, in addition to an international standard futsal team.

\section{Participants}

Altogether seventy-seven participants were included, of which fifty-six $(72.7 \%)$ were coaches from an "Advanced Youth Award" for coaching young players, and twenty-one participants (27.3\%, players and coaches) were involved in the showcase game. The advanced youth award is the highest national award for coaching youth soccer in England. Utilising the existing Advanced Youth Award cohort allowed for the recruitment of a sample of the most elite 
professional youth coaches in England. The participants worked with a mix of different age groups (Under 9 to Under 18), and for clubs with different ranking categorisations as part of the EPPP structure discussed earlier. Reflecting the high-level nature of the participants in this study, the fifty-six coaches (72.7\%) surveyed had a minimum coaching qualification of 'UEFA B'/Level 3 (N=29 'UEFA B', and N=27 'UEFA A').

The additional twenty-one participants included eleven (14.3\%) International Level U21s futsal players and eight (10.4\%) English Premier League U21s soccer players, with the remaining surveys given to three $(2.6 \%)$ coaches of the competing teams.

\section{Materials and Procedures}

Data Collection. Ethical approval was granted from the local university research ethics committee (Reference Number: BAHSS 372) and informed consent was obtained from all participants. Participants were reassured that their data would remain confidential. A survey method was adopted with participant perceptions of skill acquisition in futsal and its potential skills transfer to soccer assessed. Participants were surveyed before and after the aforementioned competitive 'showcase' futsal match. The futsal match was officiated in keeping with the rules for competition set by FIFA and UEFA, allowing observers who previously may not have seen competitive futsal to provide their opinions based on an 'authentic' futsal experience.

Instruments. Surveys were used in order to gauge the perceptions of the participants. These were 'piloted' prior to testing to remove any misunderstandings, inconsistencies or inappropriate response options. Following initial background questions, the survey consisted of multiple choice questioning, split into sections devised to assess perceptions towards a 
variety of constraints of futsal. A 5 point 'Likert scale' (strongly agree, strongly disagree) was used to measure the strength of responses. The survey was delivered in two parts, 30 minutes before and immediately following the competitive futsal match. This was done to allow the present authors to judge the perceptions of coaches who did not have any prior exposure or understanding of futsal.

\section{Data Analysis}

Data analyses were completed using SPSS (version 21, SPSS, Chicago, USA). Descriptive data included frequencies and percentages.

\section{Results}

Table 1 presents the questionnaire results both before and after the showcase game. Results broadly suggest a positive perception before the showcase game, which was strengthened further having observed a futsal match. Participants also reported that futsal could be positive for soccer talent development, with a high level of importance to soccer and that governing bodies should consider its use as part of the microstructures of talent development. Pre- and post-match values ranged from 40.3-64.9\% agreed and 19.5\%-33.8\% strongly agreed. Regarding the constraints of futsal, the majority of respondents were generally neutral on whether these constraints better replicate 11 a-side soccer than other SSG's, although a general trend for more positive reviews was observed post-match.

Table 2 presents data on the perceptions of respondents on the primary skills required in futsal and soccer with results suggesting a high similarity between game formats. Four of the top five skills selected were the same for both formats: decision making, ball control, passing and 
awareness (range 32-63\%). Creativity being the additional skill chosen for futsal and mental toughness for soccer.

Data based on the type of constraints futsal provides participants as a consequence of rules and regulations of futsal are reported in Table 3. Results show a generally positive perception towards the use of futsal in skill acquisition for soccer with a strong agreement to statements provided. For example, positive perceptions can be seen for many constraints such as; $89.6 \%$ strongly agreed or agreed that the pitch size improves skills, $88.3 \%$ strongly agreed or agreed that the pass back rule enhances ball reception skills, and $89.2 \%$ strongly agreed or agreed that futsal develops multifunctional players. Participants also generally perceived many of these skills as important to soccer talent development. For example, $81.3 \%$ respondents suggested that the pitch size in futsal can enhance skill development and is either very important or important to soccer. Meanwhile, $81.8 \%$ suggested that futsal can develop multifunctional players and is important to soccer. However, data shows coaches' perceptions were weaker for rules which differ strongly to soccer, such as the fly keeper rule and no off-sides in futsal. Only $54.6 \%$ felt that the fly keeper rule was very important or important to soccer talent development. Meanwhile, a low percentile (37.7\%) perceived that no offside in futsal was very important or important to soccer talent development.

Table 4 presents the concluding data collected post-game, with overarching comments about the use of futsal. Generally, responses were extremely positive towards the use of futsal as part of a talent development processes for soccer. Over $90 \%$ of respondents said they felt futsal could be useful for soccer TD and would consider it as part of their future coaching program.

\section{Discussion}


The main purpose of this study was to examine the potential use of futsal as a talent development tool for soccer. Through investigating the perceptions of high-level youth coaches and players, futsal and its potential positive transfer to soccer play were assessed. The results broadly suggest positive coach perceptions regarding futsal, both prior and after a showcase game involving an International Under-21s futsal team and a Premier League Under21s team. Concluding responses given 'post-game' showed that a large majority of coaches ( $90 \%)$ suggested that futsal could be useful for soccer talent development. In addition, the large majority $(\sim 91 \%)$ stated they would consider the use of futsal in their training/games program. Given the high-level nature of participants, this data is valuable, suggesting a strength of perception that should be acknowledged and considered by governing bodies, club stakeholders and coaches alike. The transfer of skills acquired through futsal participation is a crucial, underpinning query for its potential use as a talent development tool for the 11 a-side format. Responses to key questions posed both before and after the present showcase futsal game support the notion that futsal and soccer carry significant similarities, which according to Causer \& Ford (2014) are decisive to enable positive transfer across sports. Prior to the observation of the futsal match, $\sim 86 \%$ (strongly agree $=33.8 \%$, agree $=51.9 \%$ ) of participants suggested that futsal can develop skills that successfully transfer into soccer. Perceptions regarding similarity became more positive post-game, with $\sim 92 \%$ (strongly agree $=27.3 \%$, agree $=64.9 \%$ ) of participants suggesting that futsal skills can successfully transfer into soccer. Further questioning in the survey allowed for analysis of the particular skills that participants perceive as important in both sports. The survey required participants to identify in their opinion, the most important skills in both futsal and soccer. Of the top five skills identified for both game formats, four featured on both lists: decision making, ball control, awareness, and passing. These results imply that participants perceive a high similarity between game formats, supporting theories previously suggested regarding the skills required in futsal and soccer 
respectively (Yiannaki et al., 2018). Research suggests that this high similarity is conducive to potential skill transfer (Causer \& Ford, 2014) and could provide a rationale for the use of futsal in soccer talent development programs. Nevertheless, there is an additional need for applied research examining skill transfer potential. Future work could consider specific testing methodologies in a soccer context following the completion of a futsal intervention program, assessing the potential impact and transferability of skills acquired.

If futsal is delivered in its authentic format abiding by the rules, equipment, and facilities, a games format can be created with fluctuating playing demands requiring constant tactical responses (Yiannaki et al., 2018). However, an understanding of the specific constraints futsal applies to participants is crucial (Davids, Button, \& Bennet, 2008; Travassos et al., 2017; Uehara, Button, Falcous, \& Davids, 2016), especially when comparing futsal and other forms of SSG (Aguiar et al., 2012). In the present study, coach perceptions of the specific constraints of futsal were extremely positive, thus these elements could be very important to soccer (Table 3). Responses suggested using a futsal ball can help develop first touch and ball manipulation skills which were also stated as important in soccer. This constraint could influence the way coaches utilise equipment related constraints to develop skills in both sports (Davids et al., 2008; Renshaw, Chow, Davids, \& Hammond, 2010; Travassos et al., 2017). Respondents also felt that futsal rules can develop creativity, which authors often suggest is an attribute revered in elite level sport (Memmert, Baker, \& Bertsch, 2010). Survey answers additionally implied that the use of pitch boundaries can facilitate accurate passing. Respondents suggested that using boundaries represents a higher similarity to 11 a-side soccer compared to other forms of SSG that use walls and no boundaries. Furthermore, results presented in Table 3 suggest that $\sim 90 \%$ of respondents perceived that the smaller pitch size can enhance ball control/manipulation skills and passing accuracy (strongly agree $=33.8 \%$, agree $=55.8 \%$ ). 
These skills acquired through futsal play could indirectly aid players to develop confidence in high-pressure situations which have been identified as an important 'coping strategy' for elite youth soccer players (Reeves, Nicholls, \& McKenna, 2009). The present findings are crucial for stakeholders from a logistical point of view as futsal could provide a training tool whilst also being an advantageous winter alternative for training and games.

Further analysis of Table 3 shows that other constraints of futsal are perceived by participants to be of pivotal value to soccer talent development. Regarding the pass back rule, $88.3 \%$ (strongly agree $=27.3 \%$, agree $=61 \%$ ) of participants suggested that in futsal this rule develops ball reception skills. Participants also suggested that Futsal rules also improved the frequency of counterattacking actions with $87 \%$ suggesting this was a skill required in futsal (strongly agree $=16.9 \%$, agree $=70.1 \%$ ) and $79.2 \%$ implying this was important to soccer. Coaches wishing to develop ball reception and counter-attacking skills should be mindful of these results, providing specific training constraints which could be applied to facilitate skill acquisition.

When considering the use of futsal participation in developing soccer skills, it is crucial to consider the specific shorter-term benefits of participation, but also the longer-term athlete development. In contrast to some sports, soccer is usually considered to be a 'late specialisation' sport requring a multitude of skills to be learnt, over a projected process of talent development (Ericsson et al., 1993; Hornig et al., 2016), with many authors investigating the microstructures of talent development (Mills et al., 2012). Results from this piece suggest that futsal could develop more multifunctional players as a consequence of the way players rotate positions on the court. This could facilitate the development of offensive and defensive skills whilst also potentially developing ambidextrous abilities, utilising left and right feet on each side of the court. Approximately $89 \%$ (strongly agree $=27.3 \%$, agree $=62.3 \%$ ) of respondents 
suggested that futsal develops multifunctional players, with $\sim 82 \%$ (strongly agree $=19.5 \%$, agree $=62.3 \%$ ) suggesting its importance to soccer talent development. Futsal match participation may be considered a tool to help develop a breadth and variety of skills which may align positively to some recommendations identified in long-term athlete development models (Bailey et al., 2010; Ford et al., 2011; Ford et al., 2012b).

This study also analysed participant perceptions of the manner some constraints could have an impact on the physical demands of futsal. Approximately $90 \%$ of participants believe the ability to make unlimited substitutions creates a high-intensity sport (strongly agree $=28.6 \%$, agree $=61 \%$ ). These results indirectly support previous work by several authors identifying the intense physical demands futsal has on both the aerobic and anaerobic energy systems (Alvarez, D'Ottavio, Vera, \& Castagna, 2009; Castagna, D'Ottavio, Vera, \& Álvarez, 2009; Karahan, 2012). Given the evolutionary trends of English soccer growing towards an increasing need for high-intensity running activity, this finding is pertinent to coaches and conditioners (Bush, Barnes, Archer, Hogg, \& Bradley, 2015). However, coach perceptions differed when considering the importance of the substitution rule in futsal and its transfer to soccer. Only $\sim 59 \%$ (very important $=14.3 \%$, important $=44.2 \%$ ) of coaches suggested this rule is important to soccer talent development. This finding could be a reflection of the contrasting substitution rules in soccer (limited substitutions) and futsal (unlimited substitutions). However, coaches should consider the impact of this constraint on the physical demands of participation, with potential benefits to fitness and conditioning (Bradley et al., 2016; Carling \& Dupont, 2011; Rampinini et al., 2008).

Despite the broadly positive responses regarding the use of futsal as a tool to develop soccer players, there are also some clear differences between the game formats, which may be pivotal. Some rules of futsal differ to soccer, with analysis showing that participants perceive these 
constraints to be unimportant in regards to soccer talent development. For example, data shows only $37.7 \%$ (very important $=7.8 \%$, important $=29.9 \%$ ) of participants considered the no offside rule in futsal to be important to soccer talent development, perhaps reflecting participant cynicism regarding skills acquisition and transfer, with contrasting rules between game formats. Practitioners should consider the impact that specific constraints have on the skills that participants acquire, manipulating playing environments to positively affect player learning (Chow, Davids, Button, \& Renshaw, 2016). In the example above, it is important from a coach's perspective to understand the impact the no offside rule has on play, perhaps with 'pivot' players making fewer runs 'in behind', but performing more 'back to goal' play, with constraints such as this rule, condensing or diluting game characteristics (Chow et al., 2016).

Other examples of constraints which participants felt were unimportant to soccer can be observed when analysing the role of futsal goalkeepers. Only $\sim 55 \%$ (very important $=9.1 \%$, important $=45.5 \%$ ) believed that the fly keeper rule is important to soccer talent development, with only $39 \%$ (strongly agree $=10.4 \%$, agree=28.6\%) of respondents perceiving that futsal goalkeepers possess enhanced technical qualities with their feet, and only $~ 55 \%$ (very important $=14.3 \%$, important $=40.3 \%$ ) believed this to be significant to soccer. This could suggest that the position specific role of a futsal goalkeeper has lower similarities to soccer goalkeepers than findings suggest for outfield players alike, potentially reducing skills transfer (Causer \& Ford, 2014). Future research should examine goalkeepers more specifically, comparing the 'specialist' skills demanded of futsal and soccer goalkeepers (RebeloGonçalves, Figueiredo, Coelho-e.-Silva, \& Tessitore, 2016), to enable conclusions to be drawn regarding transferability in this regard (Collins, Collins, MacNamara, \& Jones, 2014). 
The importance of a deeper understanding of each specific game constraint in coaching is paramount (Renshaw et al., 2010). As with all constraints utilised as a coaching modality, some are likely to condense particular actions, whilst diluting others (Uehara et al., 2016). Skilful coaches are able to manipulate constraints to enhance players' decision making, providing players with a mixture of experiences developing overall skills and learning. It is therefore decisive that coach understanding, in both game formats, is heightened by the results of this study and as a consequence, the ability to manipulate constraints to enhance player learning is developed (Renshaw et al., 2010; Travassos, Duarte, Vilar, Davids, \& Araújo, 2012; Uehara et al., 2016). The need for a comprehensive understanding reflects the complex nature of coaching, which is more important than the training modality itself (Memmert et al., 2010). Future research needs to explore the quantity of futsal that could be appropriate in soccer talent development, with a 'balanced diet' of microstructures precisely delivered. To facilitate this, researchers should consider analysing the specific behaviours which futsal participants display in real competitive matches, examining the skills participants are likely to acquire, and therefore providing coaches with a framework for optimising constraints-led coaching (Davids et al., 2008; Renshaw et al., 2010; Travassos et al., 2017). This research will allow for a comparison between SSG formats, and to soccer performance, elucidating potential skills transfer.

The need for an effective philosophy both as an individual coach and collectively as a club and/or country is essential in ensuring talent development programs follow consistent methodologies (Cassidy, Jones, \& Potrac, 2009), with positive examples existing of this successful implementation (Grossmann \& Lames, 2015; Horrocks et al., 2016). One example could be in England, where a philosophy (marketed as the England 'DNA') has recently been created (The FA, 2015). A key question for the present paper is whether results indicate an 
association between the desired philosophy of a club/country, and skills acquired through futsal participation. Data in this study suggests that many of the skills which respondents believe will be developed through futsal participation link closely with the stated philosophy in the England 'DNA' example (The FA, 2015). The intended philosophy in this soccer example shows specific interconnections in the ability to master the ball, 'transitions' (counterattacking), multifunctionality, and creativity, all of which are skills participants in this study believe futsal participation will develop. Thus, the present findings should be considered by clubs/countries when designing and implementing talent development programs. Given the strength of results reported by such a high-level group of coaches, utilising futsal could aid talent development, whilst aligning/supporting the stated philosophies of programs.

As discussed earlier, SSG's are a common coaching methodology (Aguiar et al., 2012), therefore comparisons to other SSG formats are vital in supporting coaches and potential curriculum development. However, results present a limitation in relation to the method employed to examine participant perceptions when comparing futsal and other forms of SSG, and this must be acknowledged. Results demonstrate a level of cynicism from respondents when asked their perception on whether "the constraints and rules of futsal replicate 11 aside soccer to a higher level than other formats of SSG" with $\sim 34 \%$ remaining neutral post game. The wording of this comparative question could be criticised, with an overly simplistic and general statement regarding 'other forms of $S S G$ '. These results may only be reflection of the high-level nature of the coaches involved in the study, whom may have a more sophisticated understanding than less qualified/experienced coaches, about how to optimally adjust the constraints of SSG's during training to respond to the needs of learners. Future research should strive to determine whether futsal has a greater impact on skill acquisition for certain attributes than other forms of SSG, potentially offering an alternative coaching methodology to existing 
microstructures and providing players with a variety of experiences to aid development (Chow et al., 2016; Davids et al., 2008).

\section{Conclusion}

To conclude, the present findings show that a large majority of coaches (89.6\%) suggested 'post-game' that futsal is useful in soccer talent development, and $90.9 \%$ would consider the use of it in their coaching/game provision. The potential for positive transfer is perceived as probable, with respondents identifying a high similarity between the sports, whilst commenting on the importance that certain constraints of futsal have on skill acquisition for soccer development. As a consequence of this paper, 'stakeholders' designing talent development curriculums should consider integrating futsal. Meanwhile, coaches can benefit from the results of this study to inform their coaching practices, utilising a constraints approach to practice in an attempt to enhance player learning.

\section{Practical Implications}

- Participants in this study perceived high similarities between futsal and soccer play, which are decisive in the potential transfer of skills between the formats. Futsal, therefore could offer a coaching methodology or SSG format to provide players with different experiences to aid skill development.

- A large percentage of participants suggested that futsal can aid the acquisition of skills which could transfer to soccer environments and would consider utilising futsal in their soccer talent development programs. Thus stakeholders and governing bodies should consider the integration of futsal into talent development curriculum design. 
- Coach perceptions of the specific constraints of futsal were extremely positive, thus these elements could also be very important to soccer talent development, informing coaching practices through the utilisation of a precise constraints approach to enhance player learning. 


\section{References}

Aguiar, M., Botelho, G., Lago, C., Maças, V., \& Sampaio, J. (2012). A review on the effects of soccer small-sided games. Journal of Human Kinetics, 33, 103-113.

Alvarez, J. C. B., D'Ottavio, S., Vera, J. G., \& Castagna, C. (2009). Aerobic fitness in futsal players of different competitive level. Journal of Strength \& Conditioning Research, 23(7), 2163-2166.

Bailey, R., Collins, D., Ford, P., MacNamara, A., Toms, M., \& Pearce, G. (2010). Participant development in sport: An academic review. Sports Coach UK.

Bradley, P. S., Archer, D. T., Hogg, B., Schuth, G., Bush, M., Carling, C., \& Barnes, C. (2016). Tier-specific evolution of match performance characteristics in the english premier league: It's getting tougher at the top. Journal of Sports Sciences, 34(10), 980987.

Bush, M., Barnes, C., Archer, D. T., Hogg, B., \& Bradley, P. S. (2015). Evolution of match performance parameters for various playing positions in the english premier league. Human Movement Science, 39, 1-11.

Carling, C., \& Dupont, G. (2011). Are declines in physical performance associated with a reduction in skill-related performance during professional soccer match-play? Journal of Sports Sciences, 29(1), 63-71.

Cassidy, T., Jones, R. L., \& Potrac, P. (2009). Understanding sports coaching: The social, cultural and pedagogical foundations of coaching practice (2nd ed.). London: Routledge. 
Castagna, C., D'Ottavio, S., Vera, J. G., \& Álvarez, J. C. B. (2009). Match demands of professional futsal: A case study. Journal of Science and Medicine in Sport, 12(4), 490494.

Causer, J., \& Ford, P. R. (2014). 'Decisions, decisions, decisions': Transfer and specificity of decision-making skill between sports. Cognitive Processing, 15(3), 385-389.

Chow, J., Y, Davids, K., Button, C., \& Renshaw, I. (2016). None-linear pedagogy in skill acquisition - an introduction (1st ed.). New York: Routledge.

Clemente, F., Couceiro, M. S., Martins, F. M. L., \& Mendes, R. (2012). The usefulness of small-sided games on soccer training. Journal of Physical Education \& Sport, 12(1), 93102.

Collins, R., Collins, D., MacNamara, A., \& Jones, M. I. (2014). Change of plans: An evaluation of the effectiveness and underlying mechanisms of successful talent transfer. Journal of Sports Sciences, 32(17), 1621-1630.

Davids, K., Button, C., \& Bennet, S. (2008). Dynamics of skill acquisition - A constraints-led approach. Human Kinetics.

Davids, K., \& Chapman, G. (2001). Adapting equipment to children's development: Does the futebol de salao lead to better acquisition of skill than regular balls? The Football Association Coaches Journal, 4(4), 38-39.

Elferink-Gemser, M., Huijgen, B. C., Lemmink, K. A. P. M., Visscher, C., \& Coelho-e-Silva, M. (2012). The changing characteristics of talented soccer players - a decade of work in groningen. Journal of Sports Sciences, 30(15), 1581-1591. 
Ericsson, K. A., Krampe, R. T., \& Tesch-Römer, C. (1993). The role of deliberate practice in the acquisition of expert performance. Psychological Review, 100(3), 363-406.

Ford, P. R., Croix, M., Lloyd, R., Meyers, R., Moosavi, M., Oliver, J., \& Williams, C. (2011). The long-term athlete development model: Physiological evidence and application. Journal of Sports Sciences, 29(4), 389-402.

Ford, P. R., Carling, C., Garces, M., Marques, M., Miguel, C., Farrant, A., Stenling, A., Moreno, J., Le Gall, F., Holmstrom, S., Salmela, J. H., \& Williams, M. (2012a). The developmental activities of elite soccer players aged under-16 years from brazil, england, france, ghana, mexico, portugal and sweden. Journal of Sports Sciences, $30(15), 1653-1663$

Ford, P. R., Collins, D., Bailey, R., Macnamara, Á, Pearce, G., \& Toms, M. (2012b). Participant development in sport and physical activity: The impact of biological maturation. European Journal of Sport Science, 12(6), 515-526.

Gagné, F. (2013). The DMGT: Changes within, beneath, and beyond. Talent Development \& Excellence, 5(1), 5-19.

Gledhill, A., Harwood, C., and Forsdyke, D. (2017). Psychosocial Factors Associated with Talent Development in Soccer: A Systematic Review. Psychology of Sport and Exercise, $31,93-112$.

Grossmann, B., \& Lames, M. (2015). From talent to professional football - youthism in german football. International Journal of Sports Science \& Coaching, 10(6), 1103-1113.

Güllich, A., \& Emrich, E. (2014). Considering long-term sustainability in the development of world class success. European Journal of Sport Science, 14 Suppl 1, S383-S397. 
Halouani, J., Chtourou, H., Gabbett, T., Chaouachi, A., \& Chamari, K. (2014). Small-sided games in team sports training: A brief review. Journal of Strength and Conditioning Research, 28(12), 3594-3618.

Hornig, M., Aust, F., \& Güllich, A. (2016). Practice and play in the development of german top-level professional football players. European Journal of Sport Science, 16(1), 96105.

Horrocks, D. E., McKenna, J., Whitehead, A., Taylor, P. J., \& Morley, A. M. (2016). Qualitative perspectives on how manchester united football club developed and sustained serial winning. International Journal of Sports Science and Coaching, 11(4), 467-477.

Karahan, M. (2012). The effect of skill-based maximal intensity interval training on aerobic and anaerobic performance of female futsal players. Biology of Sport, 29(3), 223-227.

Memmert, D., Baker, J., \& Bertsch, C. (2010). Play and practice in the development of sportspecific creativity in team ball sports. High Ability Studies, 21(1), 3-18.

Milligan, I., Borrie, A., Horn, R., \& Williams, M. (2002). Technical analysis of futebol de salao and mini-football. Insight: The Football Association Coaches Journal.

Mills, A., Butt, J., Maynard, I., \& Harwood, C. (2012). Identifying factors perceived to influence the development of elite youth football academy players. Journal of Sports Sciences, 30(15), 1593-1604.

Oppici, L., Panchuk, D., Serpiello, F., R., \& Farrow, D. (2017). Long-term practice with domain-specific task constraints influences perceptual skills. Frontiers in Psychology, 8. 
Rampinini, E., Impellizzeri, F. M., Castagna, C., Azzalin, A., Bravo, D. F., \& Wisloff, U. (2008). Effect of match-related fatigue on short-passing ability in young soccer players. Medicine \& Science in Sports \& Exercise, 40(5), 934-942.

Rebelo-Gonçalves, R., Figueiredo, A. J., Coelho-e.-Silva, M. J., \& Tessitore, A. (2016). Assessment of technical skills in young soccer goalkeepers: Reliability and validity of two goalkeeper-specific tests. Journal of Sports Science \& Medicine, 15(3), 516-523.

Reeves, C. W., Nicholls, A. R., \& McKenna, J. (2009). Stressors and coping strategies among early and middle adolescent premier league academy soccer players: Differences according to age. Journal of Applied Sport Psychology, 21(1), 31-48.

Renshaw, I., Chow, J. Y., Davids, K., \& Hammond, J. (2010). A constraints-led perspective to understanding skill acquisition and game play: A basis for integration of motor learning theory and physical education praxis? Physical Education \& Sport Pedagogy, 15(2), 117-137.

Sturgess, P. (2017). Futsal: Training, technique and tactics. A\&C Black Advantage,

The FA. (2015). England 'DNA'. Retrieved from https://community.thefa.com/england_dna/p/play

The Premier League. (2011). Elite player performance plan. London: The Premier League.

Travassos, B., Araujo, D., \& Davids, K. (2017). Is futsal a donor sport for football? Exploiting complementarity for early diversification in talent development. The Journal of Science and Medicine Football, in press. 
Travassos, B., Duarte, R., Vilar, L., Davids, K., \& Araújo, D. (2012). Practice task design in team sports: Representativeness enhanced by increasing opportunities for action. Journal of Sports Sciences, 30(13), 1447-1454.

UEFA. (2017). UEFA futsal - master the ball. Retrieved from http://www.uefa.com/MultimediaFiles/Download/competitions/General/02/16/14/04/216 1404_DOWNLOAD.pdf

Uehara, L., Button, C., Falcous, M., \& Davids, K. (2016). Contextualised skill acquisition research: A new framework to study the development of sport expertise. Physical Education and Sport Pedagogy, 21(2), 153-168.

Unnithan, V., White, J., Georgiou, A., Iga, J., \& Drust, B. (2012). Talent identification in youth soccer. Journal of Sports Sciences, 30(15), 1719-1726.

Yiannaki, C., Carling, C., \& Collins, D. (2018). Could futsal hold the key to developing the next generation of youth soccer players? Science and Medicine in Football. 2(1), 71-74. 
Table 1 -Responses to key introductory questions: frequency, percentiles, and variance before and after the observation of a competitive elite Futsal match.

\begin{tabular}{|c|c|c|c|c|c|c|c|c|c|c|c|c|}
\hline \multirow[t]{2}{*}{ Question } & \multicolumn{6}{|c|}{ Thoughts on Statement } & \multicolumn{6}{|c|}{ Importance to Football } \\
\hline & $\begin{array}{c}\text { Strongly } \\
\text { Agree }\end{array}$ & Agree & Neutral & Disagree & $\begin{array}{l}\text { Strongly } \\
\text { Disagree }\end{array}$ & $\begin{array}{c}\text { Not } \\
\text { Stated }\end{array}$ & $\begin{array}{c}\text { Very } \\
\text { Important }\end{array}$ & Important & Neutral & Irrelevant & $\begin{array}{c}\text { Very } \\
\text { Irrelevant }\end{array}$ & $\begin{array}{c}\text { Not } \\
\text { Stated }\end{array}$ \\
\hline $\begin{array}{l}\text { Pre-Match - Futsal Can Develop Skills } \\
\text { Transferable Skills for Football? } \\
\text { (percentile shown in brackets) }\end{array}$ & $\begin{array}{c}26 \\
(33.8 \%)\end{array}$ & $\begin{array}{c}40 \\
(51.9 \%)\end{array}$ & $\begin{array}{c}9 \\
(11.7 \%)\end{array}$ & $\begin{array}{c}1 \\
(1.3 \%)\end{array}$ & $\begin{array}{c}0 \\
(0 \%)\end{array}$ & $\begin{array}{c}1 \\
(1.3 \%)\end{array}$ & $\begin{array}{c}15 \\
(19.5 \%)\end{array}$ & $\begin{array}{c}36 \\
(46.8 \%)\end{array}$ & $\begin{array}{c}20 \\
(26 \%)\end{array}$ & $\begin{array}{c}2 \\
(2.6 \%)\end{array}$ & $\begin{array}{c}0 \\
(0 \%)\end{array}$ & $\begin{array}{c}4 \\
(5.2 \%)\end{array}$ \\
\hline $\begin{array}{c}\text { Post-Match - Futsal Can Develop Skills } \\
\text { Transferable Skills for Football? } \\
\text { (percentile shown in brackets) }\end{array}$ & $\begin{array}{c}21 \\
(27.3 \%)\end{array}$ & $\begin{array}{c}50 \\
(64.9 \%)\end{array}$ & $\begin{array}{c}1 \\
(1.3 \%)\end{array}$ & $\begin{array}{c}1 \\
(1.3 \%)\end{array}$ & $\begin{array}{c}0 \\
(0 \%)\end{array}$ & $\begin{array}{c}4 \\
(5.2 \%)\end{array}$ & $\begin{array}{c}18 \\
(23.4 \%)\end{array}$ & $\begin{array}{c}43 \\
(55.8 \%)\end{array}$ & $\begin{array}{c}10 \\
(13 \%)\end{array}$ & $\begin{array}{c}1 \\
(1.3 \%)\end{array}$ & $\begin{array}{c}0 \\
(0 \%)\end{array}$ & $\begin{array}{c}5 \\
(6.5 \%)\end{array}$ \\
\hline $\begin{array}{c}\text { Pre-Match - EPPP should structure Futsal into } \\
\text { Provision? } \\
\text { (percentile shown in brackets) }\end{array}$ & $\begin{array}{c}15 \\
(19.5 \%)\end{array}$ & $\begin{array}{c}37 \\
(48.1 \%)\end{array}$ & $\begin{array}{c}19 \\
(24.7 \%)\end{array}$ & $\begin{array}{c}5 \\
(6.5 \%)\end{array}$ & $\begin{array}{c}0 \\
(0 \%)\end{array}$ & $\begin{array}{c}1 \\
(1.3 \%)\end{array}$ & $\begin{array}{c}11 \\
(14.3 \%)\end{array}$ & $\begin{array}{c}33 \\
(42.9 \%)\end{array}$ & $\begin{array}{c}27 \\
(35.1 \%)\end{array}$ & $\begin{array}{c}4 \\
(5.2 \%)\end{array}$ & $\begin{array}{c}0 \\
(0 \%)\end{array}$ & $\begin{array}{c}2 \\
(2.6 \%)\end{array}$ \\
\hline $\begin{array}{c}\text { Post-Match - EPPP should structure Futsal } \\
\text { into Provision? } \\
\text { (percentile shown in brackets) }\end{array}$ & $\begin{array}{c}19 \\
(24.7 \%)\end{array}$ & $\begin{array}{c}31 \\
(40.3 \%)\end{array}$ & $\begin{array}{c}19 \\
(24.7 \%)\end{array}$ & $\begin{array}{c}4 \\
(5.2 \%)\end{array}$ & $\begin{array}{c}0 \\
(0 \%)\end{array}$ & $\begin{array}{c}4 \\
(5.2 \%)\end{array}$ & $\begin{array}{c}17 \\
(22.1 \%)\end{array}$ & $\begin{array}{c}28 \\
(36.4 \%)\end{array}$ & $\begin{array}{c}24 \\
(31.2 \%)\end{array}$ & $\begin{array}{c}3 \\
(3.9 \%)\end{array}$ & $\begin{array}{c}0 \\
(0 \%)\end{array}$ & $\begin{array}{c}5 \\
(6.5 \%)\end{array}$ \\
\hline $\begin{array}{c}\text { Pre-Match - Constraints of Futsal Replicate } 11 \\
\text { a-side Football better than other SSG's? } \\
\text { (percentile shown in brackets) }\end{array}$ & $\begin{array}{c}7 \\
(9.1 \%)\end{array}$ & $\begin{array}{c}21 \\
(27.3 \%)\end{array}$ & $\begin{array}{c}29 \\
(37.7 \%)\end{array}$ & $\begin{array}{c}17 \\
(22.1 \%)\end{array}$ & $\begin{array}{c}1 \\
(1.3 \%)\end{array}$ & $\begin{array}{c}2 \\
(2.6 \%)\end{array}$ & $\begin{array}{c}7 \\
(9.1 \%)\end{array}$ & $\begin{array}{c}18 \\
(23.4 \%)\end{array}$ & $\begin{array}{c}41 \\
(53.2 \%)\end{array}$ & $\begin{array}{c}7 \\
(9.1 \%)\end{array}$ & $\begin{array}{c}1 \\
(1.3 \%)\end{array}$ & $\begin{array}{c}3 \\
(3.9 \%)\end{array}$ \\
\hline $\begin{array}{c}\text { Post-Match - Constraints of Futsal Replicate } 11 \\
\text { a-side Football better than other SSG's? } \\
\text { (percentile shown in brackets) }\end{array}$ & $\begin{array}{c}12 \\
(15.6 \%)\end{array}$ & $\begin{array}{c}28 \\
(36.4 \%)\end{array}$ & $\begin{array}{c}26 \\
(33.8 \%)\end{array}$ & $\begin{array}{c}6 \\
(7.8 \%)\end{array}$ & $\begin{array}{c}0 \\
(0 \%)\end{array}$ & $\begin{array}{c}5 \\
(6.5 \%)\end{array}$ & $\begin{array}{c}7 \\
(9.1 \%)\end{array}$ & $\begin{array}{c}28 \\
(36.4 \%)\end{array}$ & $\begin{array}{c}34 \\
(44.2 \%)\end{array}$ & $\begin{array}{c}2 \\
(2.6 \%)\end{array}$ & $\begin{array}{c}0 \\
(0 \%)\end{array}$ & $\begin{array}{c}6 \\
(7.8 \%)\end{array}$ \\
\hline
\end{tabular}


Table 2 - Perception of participants regarding key attributes for football and futsal.

\begin{tabular}{|c|c|c|c|c|c|}
\hline Percentile & $\begin{array}{l}\text { Q18 } \\
\text { Accumulative } \\
\text { Totals }\end{array}$ & Futsal Quality & Football Quality & $\begin{array}{l}\text { Q17 Accumulative } \\
\text { Totals }\end{array}$ & Percentile \\
\hline $68.8 \%$ & 53 & $\begin{array}{l}\text { Decision } \\
\text { Making }\end{array}$ & Decision Making & 63 & $81.8 \%$ \\
\hline $61.0 \%$ & 47 & Ball control & Ball control & 39 & $50.7 \%$ \\
\hline $48.1 \%$ & 37 & Creativity & Awareness & 35 & $45.5 \%$ \\
\hline $41.6 \%$ & 32 & Awareness & $\begin{array}{l}\text { Mental } \\
\text { Toughness }\end{array}$ & 34 & $44.2 \%$ \\
\hline $33.8 \%$ & 26 & Passing & Passing & 33 & $42.9 \%$ \\
\hline $24.7 \%$ & 19 & Dribbling & Self Confidence & 25 & $32.5 \%$ \\
\hline $22.1 \%$ & 17 & $\begin{array}{l}\text { Self } \\
\text { Confidence }\end{array}$ & Creativity & 18 & $23.4 \%$ \\
\hline $22.1 \%$ & 17 & Agility & Anticipation & 13 & $16.9 \%$ \\
\hline $20.8 \%$ & 16 & Missing & Height & 10 & $13.0 \%$ \\
\hline $18.2 \%$ & 14 & $\begin{array}{l}\text { Mental } \\
\text { Toughness }\end{array}$ & Dribbling & 8 & $10.4 \%$ \\
\hline $13.0 \%$ & 10 & Speed & Missing & 8 & $10.4 \%$ \\
\hline $11.7 \%$ & 9 & Anticipation & Shooting & 7 & $9.1 \%$ \\
\hline $9.1 \%$ & 7 & Shooting & Endurance & 6 & $7.8 \%$ \\
\hline $3.9 \%$ & 3 & Endurance & Agility & 5 & $6.5 \%$ \\
\hline $1.3 \%$ & 1 & Strength & Strength & 3 & $3.9 \%$ \\
\hline $0.0 \%$ & 0 & Heading & Heading & 1 & $1.3 \%$ \\
\hline $0.0 \%$ & 0 & Height & Speed & 0 & $0.0 \%$ \\
\hline
\end{tabular}


Table 3 - Frequencies in response to survey questions on the constraints of Futsal.

\begin{tabular}{|c|c|c|c|c|c|c|c|c|c|c|c|c|}
\hline \multirow[t]{2}{*}{ Question - Constraints of Futsal } & \multicolumn{6}{|c|}{ Thoughts on Statement } & \multicolumn{6}{|c|}{ Importance to Football } \\
\hline & $\begin{array}{c}\text { Strongly } \\
\text { Agree }\end{array}$ & Agree & Neutral & Disagree & $\begin{array}{l}\text { Strongly } \\
\text { Disagree }\end{array}$ & $\begin{array}{c}\text { Not } \\
\text { Stated }\end{array}$ & $\begin{array}{c}\text { Very } \\
\text { Important }\end{array}$ & Important & Neutral & Irrelevant & $\begin{array}{c}\text { Very } \\
\text { Irrelevant }\end{array}$ & $\begin{array}{c}\text { Not } \\
\text { Stated }\end{array}$ \\
\hline $\begin{array}{l}\text { Ball - Question } 1 \text { - The Futsal Ball Can Develop a } \\
\text { Good First Touch \& Ball Manipulation? } \\
\text { (percentile shown in brackets) }\end{array}$ & $\begin{array}{c}18 \\
(23.4 \%)\end{array}$ & $\begin{array}{c}44 \\
(57.1 \%)\end{array}$ & $\begin{array}{c}11 \\
(14.3 \%)\end{array}$ & $\begin{array}{c}4 \\
(5.2 \%)\end{array}$ & $\begin{array}{c}0 \\
(0 \%)\end{array}$ & $\begin{array}{c}0 \\
(0 \%)\end{array}$ & $\begin{array}{c}20 \\
(26 \%)\end{array}$ & $\begin{array}{c}38 \\
(49.4 \%)\end{array}$ & $\begin{array}{c}14 \\
(18.2 \%)\end{array}$ & $\begin{array}{c}4 \\
(5.2 \%)\end{array}$ & $\begin{array}{c}0 \\
(0 \%)\end{array}$ & $\begin{array}{c}1 \\
(1.3 \%)\end{array}$ \\
\hline $\begin{array}{c}\text { Ball - Question } 2 \text { - The Futsal Ball Can Develop } \\
\text { Creativity and Individual Skills? } \\
\text { (percentile shown in brackets) }\end{array}$ & $\begin{array}{c}17 \\
(22.1 \%)\end{array}$ & $\begin{array}{c}46 \\
(59.7 \%)\end{array}$ & $\begin{array}{c}14 \\
(18.2 \%)\end{array}$ & $\begin{array}{c}0 \\
(0 \%)\end{array}$ & $\begin{array}{c}0 \\
(0 \%)\end{array}$ & $\begin{array}{c}0 \\
(0 \%)\end{array}$ & $\begin{array}{c}13 \\
(16.9 \%)\end{array}$ & $\begin{array}{c}44 \\
(57.1 \%)\end{array}$ & $\begin{array}{c}18 \\
(23.4 \%)\end{array}$ & $\begin{array}{c}1 \\
(1.3 \%)\end{array}$ & $\begin{array}{c}0 \\
(0 \%)\end{array}$ & $\begin{array}{c}1 \\
(1.3 \%)\end{array}$ \\
\hline $\begin{array}{c}\text { Boundaries - Question } 1 \text { - The Use of Boundaries } \\
\text { Can Create Accurate Passing? } \\
\text { (percentile shown in brackets) }\end{array}$ & $\begin{array}{c}16 \\
(20.8 \%)\end{array}$ & $\begin{array}{c}43 \\
(55.8 \%)\end{array}$ & $\begin{array}{c}14 \\
(18.2 \%)\end{array}$ & $\begin{array}{c}3 \\
(3.9 \%)\end{array}$ & $\begin{array}{c}0 \\
(0 \%)\end{array}$ & $\begin{array}{c}1 \\
(1.3 \%)\end{array}$ & $\begin{array}{c}20 \\
(26 \%)\end{array}$ & $\begin{array}{c}37 \\
(48.1 \%)\end{array}$ & $\begin{array}{c}15 \\
(19.5 \%)\end{array}$ & $\begin{array}{c}3 \\
(3.9 \%)\end{array}$ & $\begin{array}{c}0 \\
(0 \%)\end{array}$ & $\begin{array}{c}2 \\
(2.6 \%)\end{array}$ \\
\hline $\begin{array}{c}\text { Boundaries - Question } 2 \text { - The Use of Boundaries } \\
\text { is Better than Using Walls in 5aside? } \\
\text { (percentile shown in brackets) }\end{array}$ & $\begin{array}{c}22 \\
(28.6 \%)\end{array}$ & $\begin{array}{c}38 \\
(49.4 \%)\end{array}$ & $\begin{array}{c}12 \\
(15.6 \%)\end{array}$ & $\begin{array}{c}3 \\
(3.9 \%)\end{array}$ & $\begin{array}{c}1 \\
(1.3 \%)\end{array}$ & $\begin{array}{c}1 \\
(1.3 \%)\end{array}$ & $\begin{array}{c}16 \\
(20.8 \%)\end{array}$ & $\begin{array}{c}33 \\
(42.9 \%)\end{array}$ & $\begin{array}{c}21 \\
(27.3 \%)\end{array}$ & $\begin{array}{c}5 \\
(6.5 \%)\end{array}$ & $\begin{array}{c}0 \\
(0 \%)\end{array}$ & $\begin{array}{c}2 \\
(2.6 \%)\end{array}$ \\
\hline $\begin{array}{c}\text { Pitch - Question } 1 \text { - The Smaller Pitch in Futsal } \\
\text { Can Create Better Ball Control \& Passing Skills? } \\
\text { (percentile shown in brackets) }\end{array}$ & $\begin{array}{c}26 \\
(33.8 \%)\end{array}$ & $\begin{array}{c}43 \\
(55.8 \%)\end{array}$ & $\begin{array}{c}7 \\
(9.1 \%)\end{array}$ & $\begin{array}{c}1 \\
(1.3 \%)\end{array}$ & $\begin{array}{c}0 \\
(0 \%)\end{array}$ & $\begin{array}{c}0 \\
(0 \%)\end{array}$ & $\begin{array}{c}23 \\
(29.9 \%)\end{array}$ & $\begin{array}{c}40 \\
(51.9 \%)\end{array}$ & $\begin{array}{c}10 \\
(13 \%)\end{array}$ & $\begin{array}{c}3 \\
(3.9 \%)\end{array}$ & $\begin{array}{c}0 \\
(0 \%)\end{array}$ & $\begin{array}{c}1 \\
(1.3 \%)\end{array}$ \\
\hline $\begin{array}{c}\text { Pitch - Question } 2 \text { - The Smaller Pitch Develops } \\
\text { Confidence in Possession \& in High Pressure } \\
\text { Situations? } \\
\text { (percentile shown in brackets) }\end{array}$ & $\begin{array}{c}24 \\
(31.2 \%)\end{array}$ & $\begin{array}{c}40 \\
(51.9 \%)\end{array}$ & $\begin{array}{c}11 \\
(14.3 \%)\end{array}$ & $\begin{array}{c}1 \\
(1.3 \%)\end{array}$ & $\begin{array}{c}0 \\
(0 \%)\end{array}$ & $\begin{array}{c}1 \\
(1.3 \%)\end{array}$ & $\begin{array}{c}25 \\
(32.5 \%)\end{array}$ & $\begin{array}{c}34 \\
(44.2 \%)\end{array}$ & $\begin{array}{c}15 \\
(19.5 \%)\end{array}$ & $\begin{array}{c}1 \\
(1.3 \%)\end{array}$ & $\begin{array}{c}0 \\
(0 \%)\end{array}$ & $\begin{array}{c}2 \\
(2.6 \%)\end{array}$ \\
\hline $\begin{array}{c}\text { Pass Back Rule - Question } 1 \text { - The Pass Back } \\
\text { Rule Develops Reception Skill? } \\
\text { (percentile shown in brackets) }\end{array}$ & $\begin{array}{c}21 \\
(27.3 \%)\end{array}$ & $\begin{array}{c}47 \\
(61 \%)\end{array}$ & $\begin{array}{c}8 \\
(10.4 \%)\end{array}$ & $\begin{array}{c}1 \\
(1.3 \%)\end{array}$ & $\begin{array}{c}0 \\
(0 \%)\end{array}$ & $\begin{array}{c}0 \\
(0 \%)\end{array}$ & $\begin{array}{c}21 \\
(27.3 \%)\end{array}$ & $\begin{array}{c}36 \\
(46.8 \%)\end{array}$ & $\begin{array}{c}14 \\
(18.2 \%)\end{array}$ & $\begin{array}{c}4 \\
(5.2 \%)\end{array}$ & $\begin{array}{c}1 \\
(1.3 \%)\end{array}$ & $\begin{array}{c}1 \\
(1.3 \%)\end{array}$ \\
\hline $\begin{array}{c}\text { Strategy and Tactics - Question } 1 \text { - Rules } \\
\text { encourage Counterattacking Strategies? } \\
\text { (percentile shown in brackets) }\end{array}$ & $\begin{array}{c}13 \\
(16.9 \%)\end{array}$ & $\begin{array}{c}54 \\
(70.1 \%)\end{array}$ & $\begin{array}{c}9 \\
(11.7 \%)\end{array}$ & $\begin{array}{c}1 \\
(1.3 \%)\end{array}$ & $\begin{array}{c}0 \\
0 \%) \\
(0 \%)\end{array}$ & $\begin{array}{c}0 \\
(0 \%)\end{array}$ & $\begin{array}{c}18 \\
(23.4 \%)\end{array}$ & $\begin{array}{c}43 \\
(55.8 \%)\end{array}$ & $\begin{array}{c}14 \\
(18.2 \%)\end{array}$ & $\begin{array}{c}1 \\
(1.3 \%)\end{array}$ & $\begin{array}{c}0 \\
0 \%)\end{array}$ & $\begin{array}{c}1 \\
(1.3 \%)\end{array}$ \\
\hline
\end{tabular}




\begin{tabular}{|c|c|c|c|c|c|c|c|c|c|c|c|c|}
\hline \multirow{2}{*}{ Question - Constraints of Futsal } & \multicolumn{6}{|c|}{ Thoughts on Statement } & \multicolumn{6}{|c|}{ Importance to Football } \\
\hline & $\begin{array}{c}\text { Strongly } \\
\text { Agree }\end{array}$ & Agree & Neutral & Disagree & $\begin{array}{l}\text { Strongly } \\
\text { Disagree }\end{array}$ & $\begin{array}{c}\text { Not } \\
\text { Stated } \\
\end{array}$ & $\begin{array}{c}\text { Very } \\
\text { Important }\end{array}$ & Important & Neutral & Irrelevant & $\begin{array}{c}\text { Very } \\
\text { Irrelevant }\end{array}$ & $\begin{array}{c}\text { Not } \\
\text { Stated }\end{array}$ \\
\hline $\begin{array}{l}\text { Substitutions - The use of Roll on Roll Off subs } \\
\text { creates a higher intensity? } \\
\text { (percentile shown in brackets) }\end{array}$ & $\begin{array}{c}22 \\
(28.6 \%)\end{array}$ & $\begin{array}{c}47 \\
(61 \%)\end{array}$ & $\begin{array}{c}6 \\
(7.8 \%)\end{array}$ & $\begin{array}{c}2 \\
(2.6 \%)\end{array}$ & $\begin{array}{c}0 \\
(0 \%)\end{array}$ & $\begin{array}{c}0 \\
(0 \%)\end{array}$ & $\begin{array}{c}11 \\
(14.3 \%)\end{array}$ & $\begin{array}{c}34 \\
(44.2 \%)\end{array}$ & $\begin{array}{c}22 \\
(28.6 \%)\end{array}$ & $\begin{array}{c}8 \\
(10.4 \%)\end{array}$ & $\begin{array}{c}1 \\
(1.3 \%)\end{array}$ & $\begin{array}{c}1 \\
(1.3 \%)\end{array}$ \\
\hline $\begin{array}{c}\text { Accumulative Fouls - The Accumulative Foul } \\
\text { Rule Develops Decision making Skills and } \\
\text { removes a Reliance on Physical Aggression? } \\
\text { (percentile shown in brackets) }\end{array}$ & $\begin{array}{c}10 \\
(13 \%)\end{array}$ & $\begin{array}{c}45 \\
(58.4 \%)\end{array}$ & $\begin{array}{c}18 \\
(23.4 \%)\end{array}$ & $\begin{array}{c}2 \\
(2.6 \%)\end{array}$ & $\begin{array}{c}0 \\
(0 \%)\end{array}$ & $\begin{array}{c}2 \\
(2.6 \%)\end{array}$ & $\begin{array}{c}9 \\
(11.7 \%)\end{array}$ & $\begin{array}{c}35 \\
(45.5 \%)\end{array}$ & $\begin{array}{c}22 \\
(28.6 \%)\end{array}$ & $\begin{array}{c}8 \\
(10.4 \%)\end{array}$ & $\begin{array}{c}0 \\
(0 \%)\end{array}$ & $\begin{array}{c}3 \\
(3.9 \%)\end{array}$ \\
\hline $\begin{array}{l}\text { Goalkeepers - The Average GK in Futsal has } \\
\text { better Ball Control than Football GK? } \\
\text { (percentile shown in brackets) }\end{array}$ & $\begin{array}{c}8 \\
(10.4 \%)\end{array}$ & \begin{tabular}{|c|}
22 \\
$(28.6 \%)$
\end{tabular} & $\begin{array}{c}32 \\
(41.6 \%)\end{array}$ & $\begin{array}{c}9 \\
(11.7 \%)\end{array}$ & $\begin{array}{c}2 \\
(2.6 \%)\end{array}$ & $\begin{array}{c}4 \\
(5.2 \%)\end{array}$ & $\begin{array}{c}11 \\
(14.3 \%)\end{array}$ & $\begin{array}{c}31 \\
(40.3 \%)\end{array}$ & $\begin{array}{c}29 \\
(37.7 \%)\end{array}$ & $\begin{array}{c}2 \\
(2.6 \%)\end{array}$ & $\begin{array}{c}0 \\
(0 \%)\end{array}$ & $\begin{array}{c}4 \\
(5.2 \%)\end{array}$ \\
\hline $\begin{array}{l}\text { Goalkeepers - The Fly Keeper Rule Allows teams } \\
\text { to create Overloads and Underloads Enhancing } \\
\text { Learning? (percentile shown in brackets) }\end{array}$ & $\begin{array}{c}9 \\
(11.7 \%)\end{array}$ & $\begin{array}{c}49 \\
(63.6 \%)\end{array}$ & $\begin{array}{c}12 \\
(15.6 \%)\end{array}$ & $\begin{array}{c}1 \\
(1.3 \%)\end{array}$ & $\begin{array}{c}1 \\
(1.3 \%)\end{array}$ & $\begin{array}{c}5 \\
(6.5 \%)\end{array}$ & $\begin{array}{c}7 \\
(9.1 \%)\end{array}$ & $\begin{array}{c}35 \\
(45.5 \%)\end{array}$ & $\begin{array}{c}21 \\
(27.3 \%)\end{array}$ & $\begin{array}{c}8 \\
(10.4 \%)\end{array}$ & $\begin{array}{c}1 \\
(1.3 \%)\end{array}$ & $\begin{array}{c}5 \\
(6.5 \%)\end{array}$ \\
\hline $\begin{array}{c}\text { Goalposts - The smaller goalposts in Futsal } \\
\text { develop variety in shooting techniques? } \\
\text { (percentile shown in brackets) }\end{array}$ & $\begin{array}{c}10 \\
(13 \%)\end{array}$ & $\begin{array}{c}36 \\
(46.8 \%)\end{array}$ & $\begin{array}{c}21 \\
(27.3 \%)\end{array}$ & $\begin{array}{c}9 \\
(11.7 \%)\end{array}$ & $\begin{array}{c}0 \\
(0 \%)\end{array}$ & $\begin{array}{c}1 \\
(1.3 \%)\end{array}$ & $\begin{array}{c}9 \\
(11.7 \%)\end{array}$ & $\begin{array}{c}35 \\
(45.5 \%)\end{array}$ & $\begin{array}{c}23 \\
(29.9 \%)\end{array}$ & $\begin{array}{c}7 \\
(9.1 \%)\end{array}$ & $\begin{array}{c}0 \\
(0 \%)\end{array}$ & $\begin{array}{c}3 \\
(3.9 \%)\end{array}$ \\
\hline $\begin{array}{c}\text { No Offside Rule - No Offside rule will create bad } \\
\text { habits in how it develops players? } \\
\text { (percentile shown in brackets) }\end{array}$ & $\begin{array}{c}7 \\
(9.1 \%)\end{array}$ & \begin{tabular}{|c|}
27 \\
$(35.1 \%)$
\end{tabular} & $\begin{array}{c}26 \\
(33.8 \%)\end{array}$ & $\begin{array}{c}15 \\
(19.5 \%)\end{array}$ & $\begin{array}{c}1 \\
(1.3 \%)\end{array}$ & $\begin{array}{c}1 \\
(1.3 \%)\end{array}$ & $\begin{array}{c}6 \\
(7.8 \%)\end{array}$ & $\begin{array}{c}23 \\
(29.9 \%)\end{array}$ & $\begin{array}{c}37 \\
(48.1 \%)\end{array}$ & $\begin{array}{c}7 \\
(9.1 \%)\end{array}$ & $\begin{array}{c}1 \\
(1.3 \%)\end{array}$ & $\begin{array}{c}3 \\
(3.9 \%)\end{array}$ \\
\hline $\begin{array}{c}\text { Positions \& Rotations - The rules create more } \\
\text { multifunctional players rotating positions in play? } \\
\text { (percentile shown in brackets) }\end{array}$ & $\begin{array}{c}21 \\
(27.3 \%)\end{array}$ & \begin{tabular}{c|}
48 \\
$(62.3 \%)$
\end{tabular} & $\begin{array}{c}6 \\
(7.8 \%)\end{array}$ & $\begin{array}{c}1 \\
(1.3 \%)\end{array}$ & $\begin{array}{c}0 \\
(0 \%)\end{array}$ & $\begin{array}{c}1 \\
(1.3 \%)\end{array}$ & $\begin{array}{c}15 \\
(19.5 \%)\end{array}$ & $\begin{array}{c}48 \\
(62.3 \%)\end{array}$ & $\begin{array}{c}9 \\
(11.7 \%)\end{array}$ & $\begin{array}{c}3 \\
(3.9 \%)\end{array}$ & $\begin{array}{c}0 \\
(0 \%)\end{array}$ & $\begin{array}{c}2 \\
(2.6 \%)\end{array}$ \\
\hline
\end{tabular}


Table 4 - presents concluding post-match responses from coach following a showcase futsal match.

\begin{tabular}{|c|c|c|}
\hline \multicolumn{3}{|c|}{$\begin{array}{l}\text { Question } 4 \text { - Has the competitive match you have seen } \\
\text { made you feel Futsal could be useful for Football TD? }\end{array}$} \\
\hline & Frequency & Percent \\
\hline Yes & 69 & 89.6 \\
\hline No & 2 & 2.6 \\
\hline Not Stated & 6 & 7.8 \\
\hline Total & 77 & 100 \\
\hline \multicolumn{3}{|c|}{$\begin{array}{l}\text { Question } 5 \text { - Would you consider using Futsal as part of } \\
\text { your football coaching or games programs in the future? }\end{array}$} \\
\hline & Frequency & Percent \\
\hline Yes & 70 & 90.9 \\
\hline No & 2 & 2.6 \\
\hline Not Stated & 5 & 6.5 \\
\hline Total & 77 & 100 \\
\hline \multicolumn{3}{|c|}{$\begin{array}{l}\text { Question } 6 \text { - Is Futsal currently part of your coaching or } \\
\text { games program? }\end{array}$} \\
\hline & Frequency & Percent \\
\hline Yes & 48 & 62.3 \\
\hline No & 23 & 29.9 \\
\hline Not Stated & 6 & 7.8 \\
\hline Total & 77 & 100 \\
\hline
\end{tabular}

